\title{
アサリ標識放流試験による環境評価手法の開発
}

\author{
Marked Clam Release-recaptured Test for Environmental Evaluation

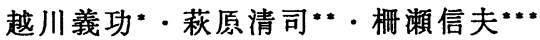

Yoshinori Koshikawa, Kiyoshi Hagiwara and Nobuo Sakurai

\begin{abstract}
Environmental evaluation to biological and ecological aspects of marine organism is an indispenable step for preserving coastal nature. To develop a new environmental evaluation method, release-recaptured test using marked shortneck clam was conducted at tidal flats in Hiroshima prefecture. The test results clarified ecological characteristics of the clam, in which could not be detected distinctly by analyses of water quality and hydraulic factors. Marked clam release-recaptured test was considered as a efficient method for environmental evaluation.
\end{abstract}

Key words; Shortneck clam, Environmental evaluation, Mitigation, Bio-monitoring.

1.はじめに

近年, 沿岸開発では環境保全が最も重視され, 環境評価とそれに関する対策が必要不可欠となっている。従来 の沿岸開発における環境評価手法は，対象水域の物理的もしくは化学的特性に関する数値解析を中心に行うシュ ミレーションが主体で, 生息している生物の特性や生息環境を総合的に把握し評価する手法は少ない。また，複 雑かつ多様な流況・水質の数值情報からどのようなものが生物に影響しているかを定量的に見極めるのは困難で ある。そこで, 本研究では複雑かつ多様な環境を評価するために, 瀬戸内海に位置する複数の砂浜域を対象として, 潜砂性二枚貝であるアサリの標識放流試験を行った。この放流した標識アサリから各地点における成長や生残，再 生産の状況などの生物的情報と水温, 塩分, 底質, 気象など物理的情報とあわせて検討することによって環境評価 を行い，標識放流試験を取り入れた環境評価手法の有効性を検討した。

\section{2. 環境評価手法の全体構成}

アサリ標識放流による環境評価のフローを図ー1に示し た。この手法は, 環境調查, 天然アサリの生息調查, 標識 放流調查によって構成されている。

環境調查は水温・塩分・底質・気象条件といった生物の 生息に関連する物理的情報を得ることが可能である。また， 天然アサリの生息調查を行うことによって対象水域のアサ リの稚貝の発生・成長, 標識アサリの追跡調查によって成 長・生残率・回収率といった生物学的情報についてそれぞ れの得られた情報を基に環境評価を行うものである。

標識放流試験では，多くの標識個体を必要とし，その精 度を上げるために標識の剥離・消失を避けなければならな い。そのため，標識放流試験に使用するアサリに対し，大 量処理が可能で剥離しにくい鉄さび標識法2)を採用して着 色処理を行った。鉄さび標識法は，貝殼全体を鉄さびによ ってコーティングするため，貝款の成長が非常にわかりや すい利点を有している（写真一 1 )。

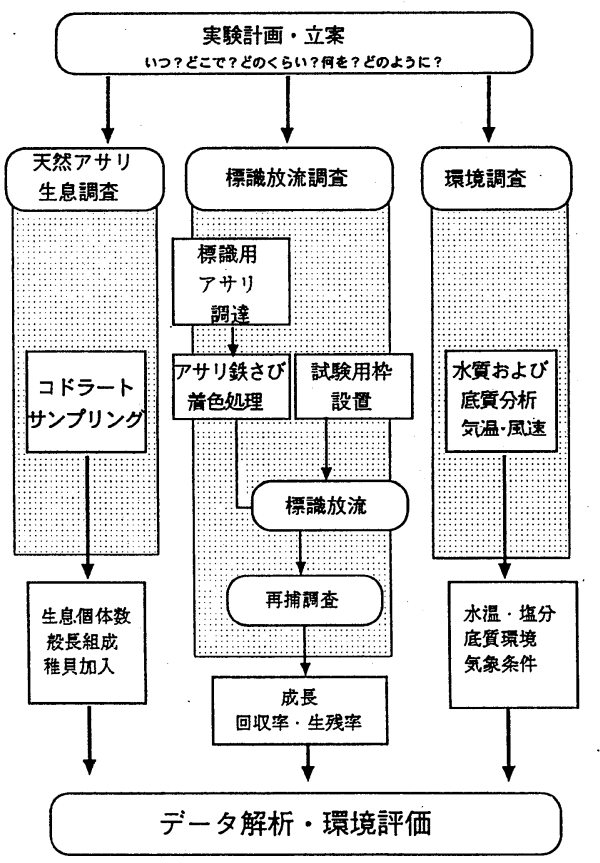

図-1アサリ標識放流による環境評価のフロー

\footnotetext{
* 正会員 鹿島建設 技術研究所葉山水産研究空（240-01 神奈川県三浦郡葉山町一色2415)

** 鹿島建設 技術研究所葉山水産研究室

*** 正会員 鹿島建設 技術研究所葉山水産研究室
} 


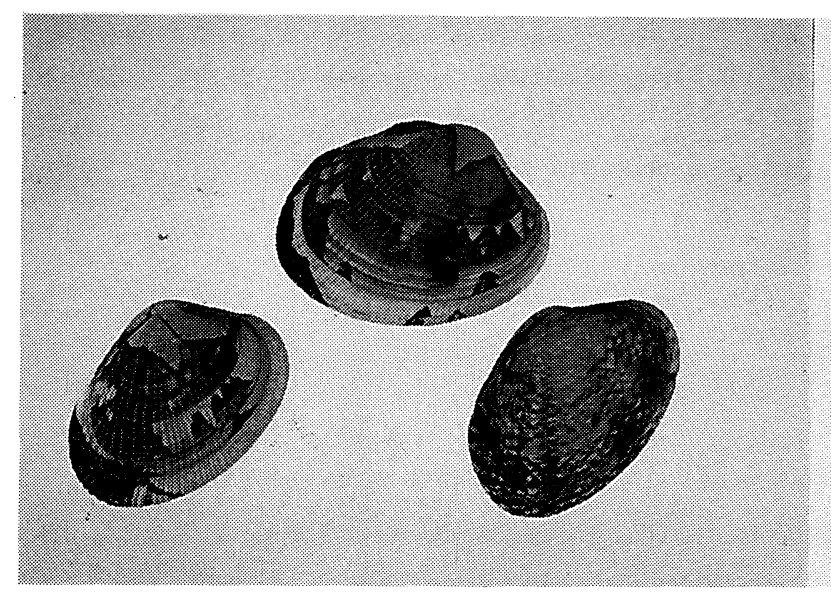

写真-1 放流45日後の標識アサリ

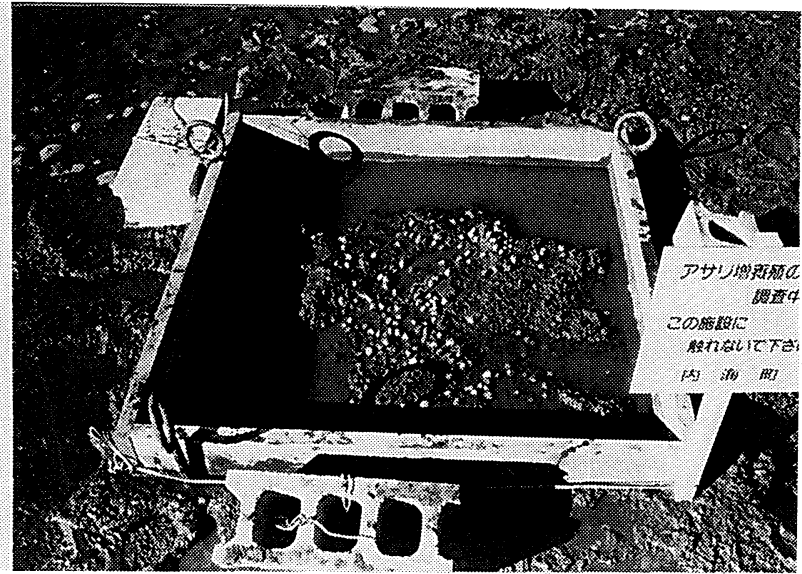

写真一2 標識アサリの放流状況

3 方法

今回の調查地点は広島県沼隈郡内海町地先の釜谷, 志 垣, 岩谷の3カ所の砂浜である(図一2)。

環境調查は調查地点において水温, 塩分, 底質（粒度 組成, 含水率, 強熱減量), 間腙水中硫化物浱度などにつ いて調查した。風向・風速と気温, 降水量は, 気象庁大 阪管区気象台福山測候所の観測記録より集計した。

天然アサリ生息調查は調查地点付近においてコドラー トサンプリングによってアサリを採集, 研究室に持ち㷌 り, 個体数, 殼長, 款高, 殼幅, 体重を集計した。

標識放流試験は1994年7月に調查地点の一つである志 垣地先の砂浜域で採集した殼長 $15 \sim 26 \mathrm{~mm}$ のアサリを鉄さ び標識法"で貝款全体を茶褐色に着色して使用し, 各調 查地点に 2 ヶ所ずつ $1 \mathrm{~m} \times 1 \mathrm{~m}$ の木製の势を砂中に設置し,

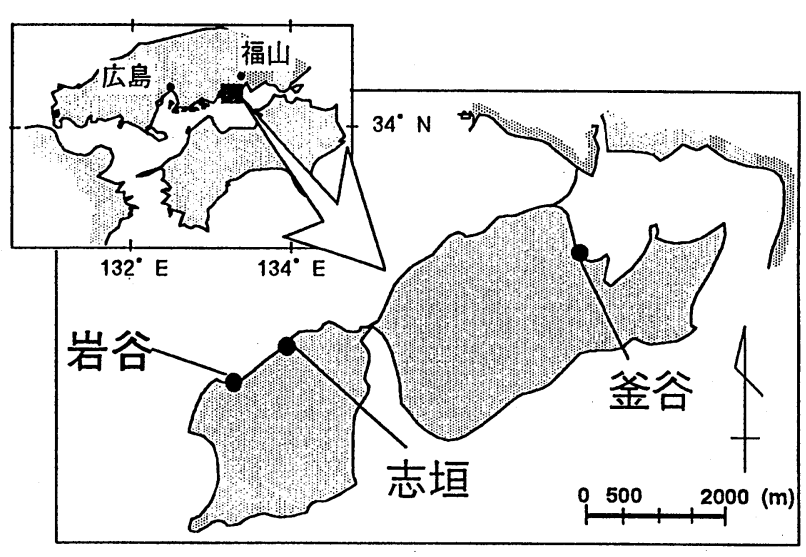

図-2 調查地点（広島県内海町）

この中に着色した標識アサリを300個体ずっを収容することによって行った（写真ー2）。放流後にそれぞれ45日，

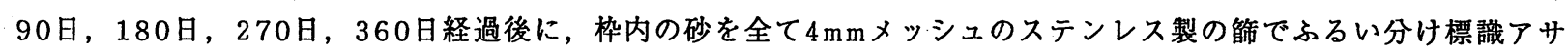
リを掘り出した。そして, 掘りたした全てのアサリについて生存個体, 死亡個体数を計数し, 標識アサリの放流個 体数と回収した標識アサリの個体数から生残率, 回収率を算出した。計数後の標識アサリは, 再度枠中に放流して 試験を継続した。また, 標識アサリの成長を追跡するために, 回収した標識アサリの中から15〜20個体を無作為に 抽出し実験室へ持ち㷌り, 殼長, 殼高, 殼幅, 体重を測定し, 貝殼の大きさの指標としてSLHW值（殼長×殼高× 款幅）を算出した。

\section{4. 結果}

\section{$4-1$ 環境}

罒一 3 に水温と塩分の測定結果を示した。水温は, 各調查地点において夏季は $26 \sim 29^{\circ} \mathrm{C}$ 示し, 冬季には $5^{\circ} \mathrm{C}$ 前後まで降下した。塩分は, 通年 $25 \sim 36 \%$ で変化し夏季に低く，冬季に高い傾向を示した。水温，塩分とも各調 查地点間では明確な差はみられなかった。表ー1に各調查地点における底質環境を示した。釜谷は他の 2 地点に比 较すると, 泥分が多く底泥中の有機物量も多いが, 志垣, 岩谷の两地点は, 砂䂣質で底泥中の有機物量は少ない。 底泥中の硫化物量も底質を反映して，釜谷が最も高い値を示した。

図一4に調查期間中における風向・風速と降水量を示した。期間中の風向・風速は，6〜10月には，南東から南 西の風が卓越するが，11月から 2 月にかけては北東から西よりの季節風が卓越し，風速も大きくなった。期間中 の降水量は 1994 年 7 月から 1994 年 12 月にかけて, 降水量が平年の 20 ～66\%と少なかった。

\section{4ー2 天然アサリの生息状況}

釜谷，志垣における天然アサリの生息状況を図ー5に示した。釜谷，志垣の两地区では，調查期間中アサリの生 息が確認されたのに対し，岩谷では1995年2月までア当りの生息を確認することができなかった。しかし，1995 年 5 月以降稚貝が出現し始めた。

アサリの生息数は9月に釜谷 732 個体 $/ \mathrm{m}^{2}$, 志垣を 232 個体 $/ \mathrm{m}^{2}$ 最高にそれ以降減少した。そして, 最も水温が 低下する 2 月には釜谷で 189 個体 $/ \mathrm{m}^{2}$, 志垣で 117 個体 $/ \mathrm{m}^{2}$, 岩谷で 0 個体 $/ \mathrm{m}^{2}$ となり，9月のビーク時の約 $25 \sim 50 \%$ となった。しかし，95年5月以降は再び増加傾向となり，95年8月には釜谷で 272 個体 $/ \mathrm{m}^{2}$, 志垣で 241 個体 $/ \mathrm{m}^{2} に$ 
表ー 1 調査地点における底質環境

\begin{tabular}{lrrr}
\hline 粒度組成 $(\%)$ & 釜谷 & 志垣 & 岩谷 \\
\hline$\geqq 0.840(\mathrm{~mm})$ & 50.8 & 58.7 & 59.0 \\
$0.840 \sim 0.251$ & 32.6 & 36.4 & 31.7 \\
$0.250 \sim 0.150$ & 7.3 & 3.4 & 4.6 \\
$0.149 \sim 0.075$ & 4.3 & 0.7 & 2.8 \\
$\leqq 0.074$ & 4.8 & 0.4 & 1.7 \\
\hline 含水率 $(\%)$ & 20.8 & 17.2 & 16.2 \\
強熱減量 $(\mathrm{g} / \mathrm{kg})$ & 14.9 & 4.2 & 5.0 \\
硫化物濃度 $(\mathrm{ppb})$ & 356 & 51 & 124 \\
均等係数 & 9.7 & 5.5 & 7.4 \\
\hline
\end{tabular}

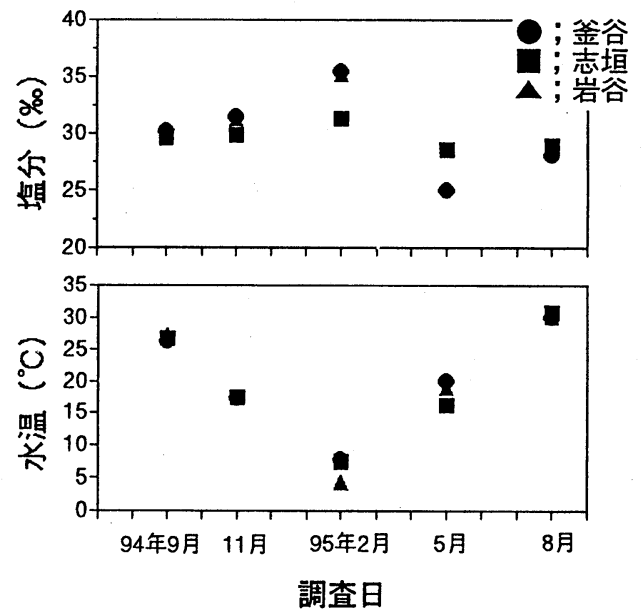

図一３調查地点における水温と塩分の測定結果
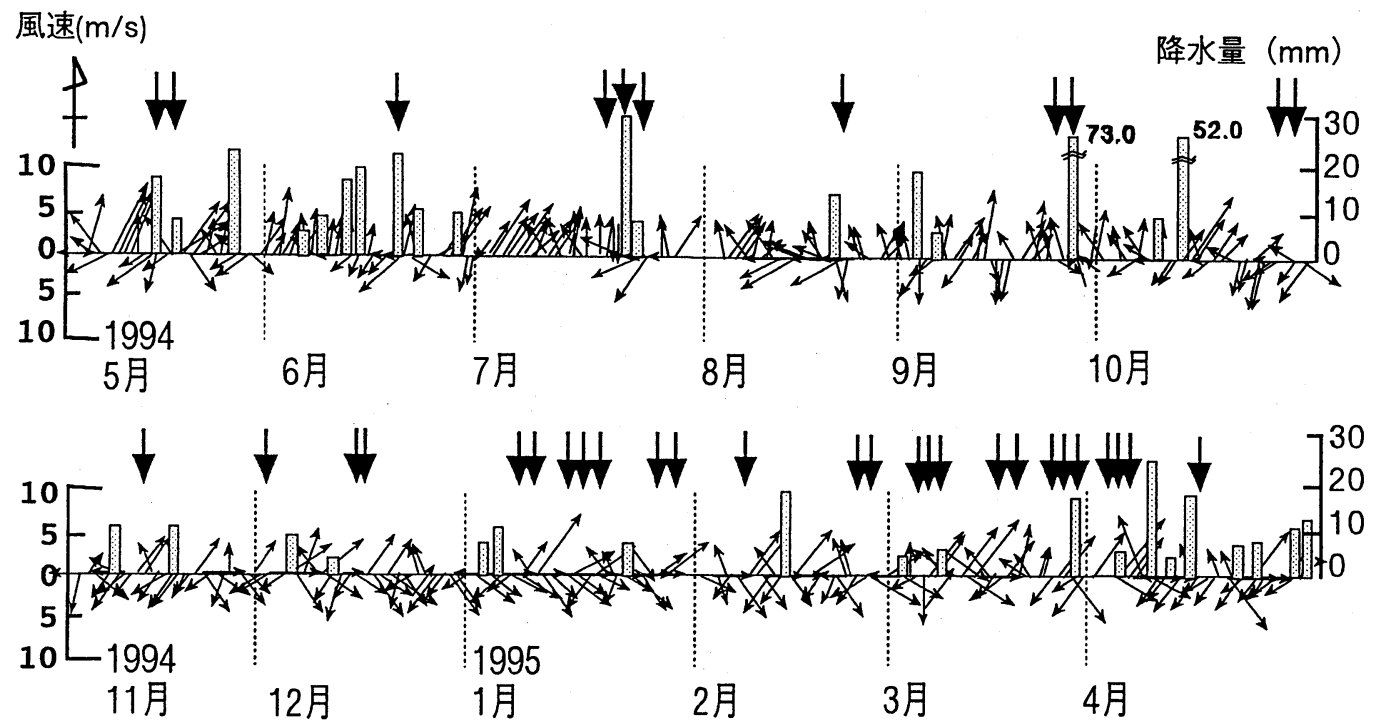

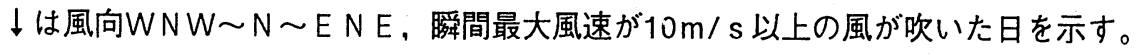

図ー4＼cjkstart福山市における風向・風速および降水量の観測結果

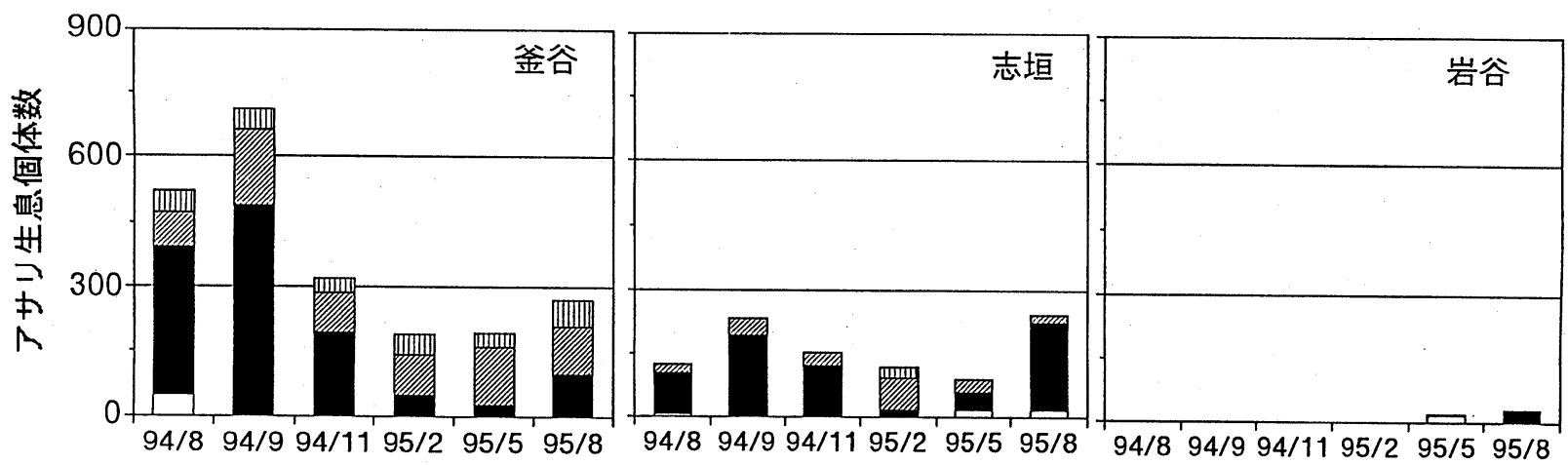

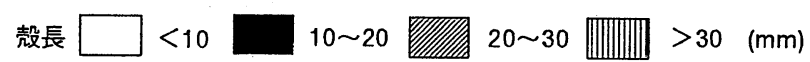

図－5 標識放流試験期間中における天然アサ!の生息状況 （左 ; 釜谷, 中央 ; 志垣, 右 ; 岩谷） 
まで回復し，前年には生息が確認されなかった岩谷でも稚貝の発生が見られ8月には 30 個体/ $\mathrm{m}^{2}$ とった。

各調查地点におけるアサリの款長組成は，釜谷では小型個体（殼長10２0 mm）の割合が高く，中型個体（㰻長 $20 \sim 30 \mathrm{~mm}$ ), 大型個体（款長 $30 \mathrm{~mm}$ ）の順に低くなるが, 水温が低下するのに伴い, この比率が逆転する。そし て，産卵期を迎える春期（95年 5 月）には産卵群となりうる殼長 $20 \mathrm{~mm}$ 以上の中・大型個体が $80 \% を$ 占めた。一方， 志垣では大型個体は周年見られず, 小型および中型個体のみで, 特に冬期（95年 2 月）には小型個体の減耗等で個 体数が減少した。

\section{$4-3$ 標識アサリの放流再捕試験}

標識アサリの成長の指標である平均SLHW值の経時変化を図ー6に示した。放流 45 日後には各地点でSLHW值は 増加したが，90日後から180日後にかけてはその伸びは停滞気味になった。同時に各地点間で差が出始めた。270 日後以降，水温の上昇に伴い標識アサリの平均SLHW值は再び増加し，岩谷，釜谷の順で高くなっており，その傾 向は水温が高い場合は上昇し，水温が低下すると停滞する傾向にあった。

各地点における標識アサリの初期放流個体数に対する回収率の変化を図ー7に示した。360日後における標識ア サリの回収率は平均 $13 \%$, 最高が釜谷の $27.5 \%$, 最低が志垣 $0 \%$ であった。特に, 志垣は減耗が著しく, 270 日 後には標識貝の再捕はできなくなった。また, 釜谷, 岩谷における確認した標識貝の死貝から算出した死亡率は $10 \%$ 以下であったが，志垣における標識貝の死亡率は $21.8 \%$ であった。

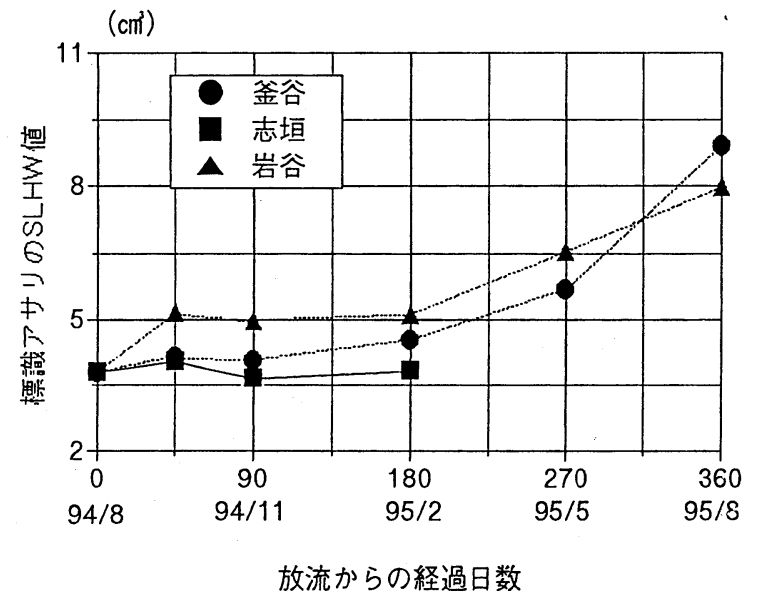

図－6＼cjkstart標識アサリのSLHW值の経時変化

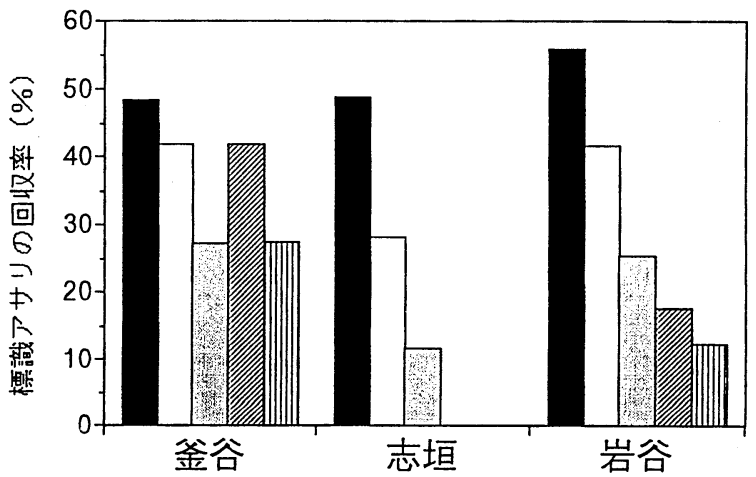

45日後 $\square$ 90日後 圆 180日後 包 270日後 而 360日後

図-7＼cjkstart標識アサリの回収率

\section{5. 考察}

アサリの成長には, 水温, 塩分, 飭料, 底質, 波浪などの環境要因が影響を及ぼす2-5) とされている。今回の標 識放流試験の結果では, 標識アサリのSLHW值の傾向は岩谷, 釜谷, 志垣の順で高く, 水温や塩分には明確な違い がみられないことから, 各調查地点での標識アサリのSLHW值の差は慨料, 底質, 波浪などの環境要因によると考

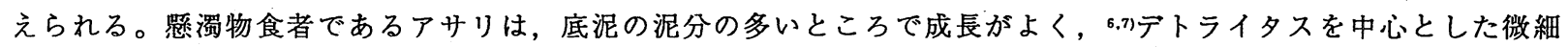
粒子でも成長可能とされ，8.9) 表ー1に示したように底泥有機物量を示す強熱減量および泥分率は釜谷が最も高く, 成長に反映されSLHW值も高い。しかし，標識アサリのSLHW值は岩谷についても釜谷と同じ成長がみられた。こ れは多くのアサリが生息する釜谷では飭料攝取の競合により成長が抑制されるためと考えられる。

各地点における標識アサリの回収率は各地点間で差異があらわれた。特に, 志垣では 1994 年11月から1995年 2 月にかけて回収率が急激に低下して, 標識アサリの流出が考えられた。この時期, 志垣では護岸基部にみられるよ うに大幅な砂の移動が生じており（写真一3），標識アサリを放流した木製の染も標識放流直後のそれと比較して も（写真一2）著しく損傷を受けていた（写真一4）。誏岸における付着生物の状況から護岸付近における砂面の上 下移動は $1 \mathrm{~m}$ 程度と推定され，季節風による波浪が激しかったことを示唆している。この現象は11月から 2 月にか けての北東から西よりの季節風が卓越し, 瞬間最大風速 $10 \mathrm{~m} / \mathrm{sec}$ 以上の風が吹く日数が多くなった時期と一致して いた。アサリは水温が $10^{\circ} \mathrm{C}$ 以下になると潜砂能力が大幅に低下する10)といったことからも，北岸に位置している 志垣では季節風に伴う波浪による転動に加え, 低水温による濾水量の低下による体力の消耗, 成長の停滞によって 減耗，流出につながったと考えられる。また、このことは標識放流における標識アサリの回収状況が波浪・砂移動 を反映することを示唆している。 


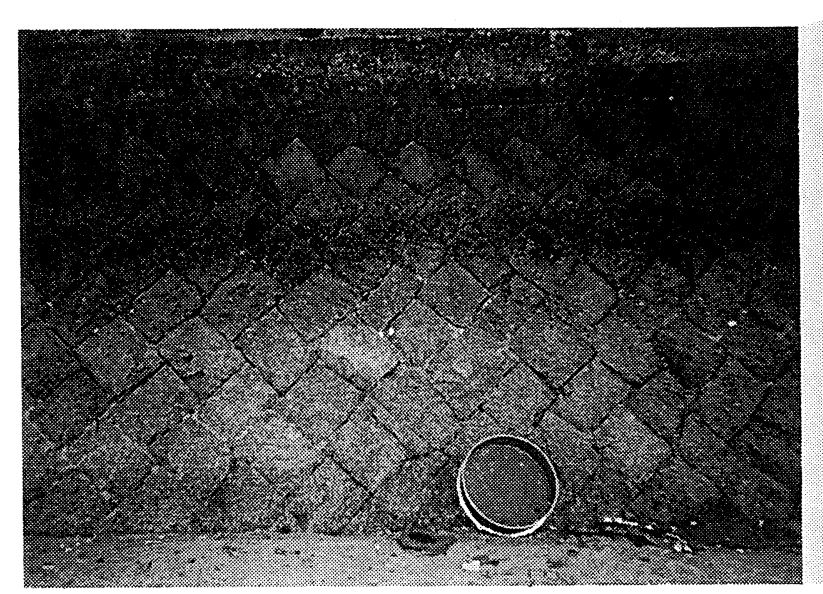

写真-3 後背護岸における砂面浸食状況

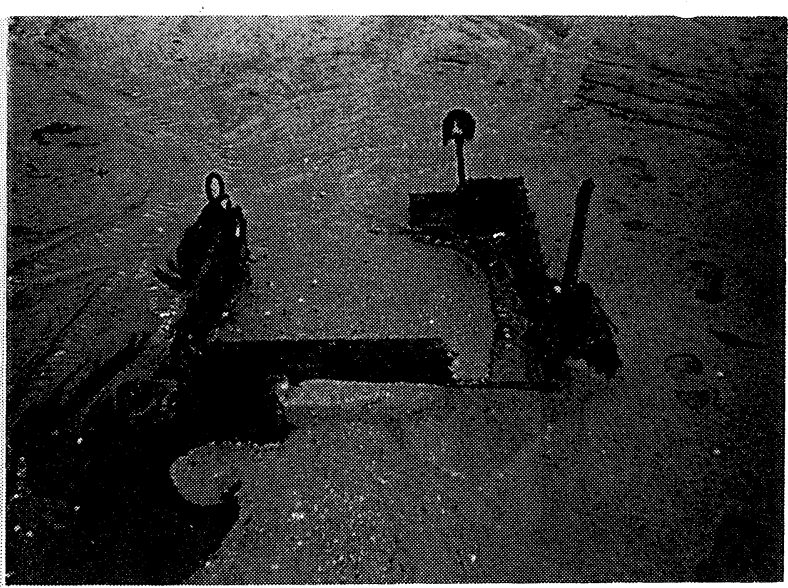

写真 -4 標識アサリ放流枠の損傷（95年2月，志垣）

標識放流試験によって，その場所における成長・生残・餌量・静穏度などの多くの情報を得ることが可能である が，天然の生息個体を調查することによってミチゲーション事業の成否を決定づける再生産について検討すること も可能である。内海町沿岸の砂浜におけるアサリ款長組成は, 秋期発生群は初复から大きく成長し, 翌年の春には 産卵可能な款長 $20 \mathrm{~mm}$ 以上に達しており, 瀬戸内海沿岸の山口・大海湾 ${ }^{11)}$ と同様に秋期発生群が資源に寄与してい ることを示している。一方, 各調查地点で春期発生個体群の定着が少ない原因は, 供給される浮遊幼生が少ないこ

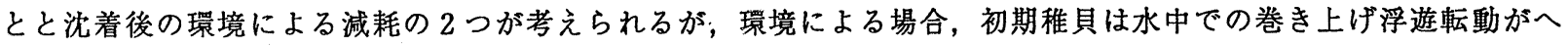
い死の主要因12)とされ，生き残ったとしても成長が良くないために冬期の低水温などによって活力が低下し減耗す る5)ため加入が少ないと考えられる。また, 稚貝期（款長 $15 \mathrm{~mm}$ 以下）は, 殼も薄く保水性も少ないので, 短時間で も干出すると呼吸や高温等の影響を受けやすく耐性の幅が狭い。特に $37^{\circ} \mathrm{C}$ 以上では 2 時間以内に死亡するとされて おり， ${ }^{13)}$ 保水性が少ない（均等係数が小さい）志垣, 岩谷では夏期の干出も春期発生個体群の加入の制限因子のひ とつになっている。このように, 内海町沿岸のアサリ資源は秋期発生群によって個体群を維持しているが，産卵可 能な殼長 $20 \mathrm{~mm}$ 以上の個体数はアサリ漁場のそれと比較しても少なく, 再生産に不可欠な浮遊幼生の供給は外部から 主であると推定される。

6. まとめ

今回の内海町地先におけるアサリ生息場数地点における調査は，鉄さび標識法による放流試験と生息実態調査を 併用することで，水理・水質テータに差が現れにくい生物を支える環境特性，特に波浪に影響する風向・風速の影 響，再生産の違いを明確に現した。底生生物相はその水域の環境要因の累積的な特性を反映しやすい14)とされ，ア サリ貝款の成長は水温, 塩分, 飭料, 底質, 波浪などの環境要因を一元化した総合指標的なものであり, 標識放流 は環境評価手法としての有効であると考えられる。

参考文献

1) Yoshinori Koshikawa, Kiyoshi Hagiwara, Boon Keng Lim and Nobuo Sakurai: A new marking method to short necked clam Ruditapes philippinarum with rust. Fisheries Science, (1997) (in press).

2 ）秋山章夫；底生動物の挙動と食物連鎖，潮間带周辺海域における浄化機能と生物生産に関する研究，昭和 59 年度研究成果報告書, 東海区水産研究所・南西海区水産研究所, pp.99-104,（1985）.

3 ）熊本のり研究所; 大規模增殖場造成事業調查絵合報告書, 玉名地区, 一アサリー, 水産庁（1979）.

4 ) 倉持英次郎; アサリの生態研究, 特に環境要素について, 水産学集成, 東京大学出版会, pp.611.655, (1957).

5 ）柿野純, 古畑和哉, 長谷川健一; 東京湾盤洲干渴における冬季のアサリのへい死要因について, 水産工学, 32 (1), pp.23-32, (1995).

6 ）沼口勝之；菊池川河口域におけるアサリ漁場の慨環境とアサリの成長，西海ブロック資源增殖部会 藻類 · 貝類研究会報, 8号, pp.59-63，(1992）

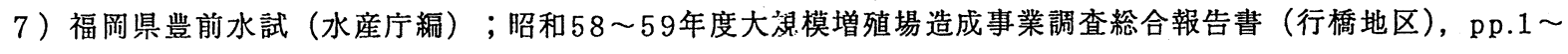
46, (1986).

8 ）黑倉寿, 黒田信行, 笠原正五郎 ; 芦田川河口域におけるアサリの生き残り条件に関する研究, 水産增殖, 35 
(4), pp.223-228., (1988).

9 ）伊藤絹子, 吉田晋, 鈴木あや子, 狩谷貞二; 超音波振動を利用した二枚貝類への投飭方法, 水産增殖, 37 (4), pp.241-246, (1989).

10）樱井泉, 瀬戸雅文, 中尾繁; ウバガイ, バカガイおよびアサリの潜砂行動に及ほす水温, 塩分および底質 粒径の影響, 日本水産学会誌, 62 (6), pp.878-885, (1996).

1 1) 井上泰；山口・大海湾におけるアサリの生態と環境について，水産土木，16（2），pp.29-35，(1979）.

12 ）渡辺栄一; 波浪及び埋没によるホッキガイ稚貝の減耗機構に関する実験的考察, 土木試験所月報, 351 , (1981).

13 ）網尾勝；アサリの増殖について，水産資源保護協会月報，217,pp.4-10

14 ）桑原連; 平潟湾の底生動物相とその分布・季節変化 (昭和 57 年度平渴湾底生生物調查報告), 横浜市公害 研資料，68，pp.67-90，（1986）. 